\title{
Distinct genetic groups of Giardia intestinalis distinguished by restriction fragment length polymorphisms
}

\author{
Peter L. Ey, ${ }^{*}$ Kumkum Khanna, $†$ Ross H. Andrews, Paul A. Manning and \\ GRAHAM MAYRHOFER \\ Department of Microbiology and Immunology, The University of Adelaide, Adelaide 5001, Australia
}

(Received 16 June 1992; accepted 13 August 1992)

\begin{abstract}
The taxonomic status of the parasitic protozoal species Giardia intestinalis depends on the morphological similarity of all Giardia isolated from humans and the presumption that Giardia are host-specific. On the basis of electrophoretic data derived from examination of 26 enzyme loci in Australian isolates, it has been proposed that G. intestinalis is a species complex comprising three or four genetically distinct (but morphologically cryptic) species. These received the tentative designations of genetic groups I-IV (R. H. Andrews, M. Adams, P. F. L. Boreham, G. Mayrhofer \& B. P. Meloni. International Journal for Parasitology 19, 183-190, 1989). In the present study, two unrelated DNA probes (one specific for a gene encoding a trophozoite surface protein, the other detecting a non-coding repetitive sequence within the $G$. intestinalis genome) were used in Southern hybridization analyses to examine 10 axenic isolates of $G$. intestinalis, established from diverse geographical regions in Australia, together with the Portland-1 isolate from the USA. Both probes identified every isolate unambiguously as belonging to one or other of two genetic clusters. Electrophoretic analysis of the same samples indicated that these clusters correspond to the previously defined genetic groups I and II. No heterogeneity was apparent within the seven group I isolates using either probe. However, when probed with the repetitive sequence, the four isolates belonging to group II exhibited small differences in banding patterns, suggesting that this group may be less homogeneous than group $I$. The consistency of the Southern blot data with the allozyme groupings confirms group I and group II as distinct genetic subgroups of $G$. intestinalis and establishes that selected restriction sites can be used as taxonomic markers for the purposes of a genetically based systematics for $G$. intestinalis.
\end{abstract}

\section{Introduction}

Present-day members of the genus Giardia are believed to have evolved from ancestral organisms that formed an early branch point in the lineage of eukaryotic cells (Sogin et al., 1989; Kabnick \& Peattie, 1991; Lanzendörfer et al., 1992). They are all anaerobic, flagellate protozoa that parasitize the intestines of vertebrates. The systematics of the genus is based on a limited number of morphological characters that are visible by light microscopy (Filice, 1952), to which have been added recently several species-specific ultrastructural characters (Erlandsen \& Bemrick, 1987; Feely, 1988;

* Author for correspondence. Tel. 8 2285389; fax 8 2240927; e-mail pey@g.adelaide.edu.au.

† Present address: Queensland Institute of Medical Research, Bramston Tce., Brisbane 4006, Australia.

Abbreviation: RFLP, restriction fragment length polymorphism(s).
Erlandsen et al., 1990). The following species have been described (reviewed by Adam, 1991): G. agilis (amphibia), G. muris (rodents, birds, reptiles), G. duodenalis (mammals, birds, reptiles), G. microti (voles and muskrats), G. ardeae (great blue heron) and G. psittaci (birds). An earlier taxonomy based on presumed host-specificity has no sound epidemiological or experimental basis (Thompson et al., 1990; Adam, 1991). Nevertheless, it is too early to discard the principle of host-specificity or host range as having little taxonomic value. The great diversity of vertebrates that are hosts to Giardia in many parts of the world, and the ancient lineage of the genus, could allow greater heterogeneity to exist at the genetic level than is obvious from morphological examination.

The species $G$. intestinalis (syn. G. lamblia) is a relic of the taxonomy based on presumed host-specificity and as such consists of all Giardia that parasitize man. G. intestinalis falls within the morphological description of the species $G$. duodenalis and the genetic relationship between human isolates and isolates from animals is a 
subject of continuing interest. Furthermore, G. intestinalis isolates exhibit heterogeneity for a number of phenotypic and genotypic characters, including surface antigens (Smith et al., 1982; Nash \& Keister, 1985), isoenzymes (Bertram et al., 1983; Baveja et al., 1986; Meloni et al., 1988, 1989; Abaza et al., 1991), DNA restriction patterns (Nash et al., 1985; de Jonckheere et al., 1989; Meloni et al., 1989; Archibald et al., 1991), chromosome patterns (Adam et al., 1988; Upcroft et al., 1989; Campbell et al., 1990; de Jonckheere et al., 1990) and sensitivity to therapeutic agents (Boreham et al., 1987; Upcroft et al., 1990). Recently, 26 allozymic characters were examined in axenic isolates of $G$. intestinalis from Australia and the isolates fell into four distinct genetic groups (Andrews et al., 1989). The definition of 'species' is difficult in asexual protozoa but the level of fixed genetic differences between these groups was greater than the differences measured by this technique between species in a variety of sexual metazoan genera (Richardson et al., 1986). It was therefore proposed that $G$. intestinalis was a species complex comprising at least three or four morphologically cryptic species.

Studies at the DNA level employing sequence analysis of ribosomal RNA genes (van Keulen et al., 1991), hybridization of DNA probes representative of individual genes (Campbell et al., 1990) and polymerase chain reaction (PCR) analysis of the gene for $\beta$-giardin (Mahbubani et al., 1992) have exploited in different ways the potential of DNA analysis as a genetic tool in establishing the systematics of Giardia. This potential is based on the vast number of genetic characters provided by the base sequence of genomic DNA. The studies have uniformly supported the separate species status of $G$. duodenalis, G. muris and G. ardeae. However, the hybridization techniques employed by Campbell et al. (1990) found overall similarity between isolates of $G$. duodenalis from human and animal sources, indicating that they can only resolve relatively large genetic differences (i.e. relatively large phylogenetic distances). PCR analyses, using primers specific for different parts of the $\beta$-giardin gene, similarly distinguished $G$. muris and $G$. ardeae from various samples of $G$. duodenalis (Mahbubani et al., 1992). The latter included both human-derived ( $G$. intestinalis) and animal-derived isolates, but the technique apparently failed to detect any difference between them.

Other studies have used restriction analysis and Southern blotting with a variety of DNA probes to detect differences between $G$. duodenalis isolates from animals and humans (Meloni et al., 1989) and between isolates of G. intestinalis (Nash et al., 1985; de Jonckheere et al., 1989; Meloni et al., 1989). Because each study analysed only a few genetic characters (i.e. restriction sites), the results can demonstrate similarities or differences for these characters between isolates but they cannot be used for the purpose of quantitative systematics or to construct phylogenies. The same considerations also apply to studies on Giardia chromosomes by pulsed-field electrophoresis, which in some cases have failed to resolve differences between isolates of $G$. intestinalis (Adam et al., 1988; de Jonckheere et al., 1990), although allowing correlation of karyotype with Australian or North American origin in another study (Upcroft et al., 1989).

In the present study, we have also compared restriction fragments from a number of in vitro cultured isolates of G. intestinalis on Southern blots (Southern, 1975), using two independent DNA probes. However, we have combined the study with allozyme electrophoresis and have therefore been able to correlate restriction fragment patterns with genetic groups defined allozymically. The results indicate that some restriction sites represent fixed genetic differences between the allozymically defined genetic groups I and II of $G$. intestinalis and they can therefore be used in the systematics of the species.

\section{Methods}

Materials. Proteinase $\mathrm{K}$, restriction endonucleases, digoxigeninlabelled dUTP, alkaline-phosphatase-labelled anti-digoxigenin antibodies and other digoxigenin labelling and detection reagents (random hexanucleotides, Klenow enzyme, etc.) were purchased from Boehringer Mannheim. RNAase A, herring sperm DNA and 5-bromo-4chloro-3-indolyl phosphate were obtained from Sigma, and positively charged nylon membranes (Hybond $\mathrm{N}^{+}$) were from Amersham. All other reagents were of analytical grade.

Source of $G$. intestinalis isolates and cultivation. The Ad-1 and Ad-2 isolates have been described elsewhere (Andrews et al., 1989). Isolates Ad-3, Ad-6 and Ad-10 were obtained initially by inoculating newborn mice with cysts derived from human stool samples and they were later established in axenic culture (Mayrhofer et al., 1992) in TY1-S33 medium (Keister, 1983) supplemented with ox bile. The Ad-113 isolate was similarly established from trophozoites in a duodenal aspirate sample (Mayrhofer et al., 1992). Clonal populations of these isolates were established from single trophozoites collected under direct microscopic examination (Andrews et al., 1992). Axenic cultures of BRIS/83/HEPU/136, BRIS/87/HEPU/768, BRIS/83/HEPU/99 (clone 2) and BRIS/87/HEPU/694 were provided by Dr P. F. L. Boreham (Queensland Institute of Medical Research, Brisbane, Australia). Two clonal cultures were established from BRIS/83/HEPU/136 (Bris$136 / \mathrm{Cl}$ and Bris-136/C2), each giving identical allozyme and DNA profiles. Axenic cultures of the isolates BAH-1 (Meloni et al., 1988) and BAH-12 (Meloni et al., 1989) were obtained from Dr R. C. A. Thompson (Murdoch University, Perth, Australia). The Portland-1 isolate (Meyer, 1976) was obtained from Professor E. A. Meyer (Portland, Oregon, USA). Analyses were performed on clonal populations of trophozoites, except in the cases of BRIS/87/ HEPU/768, BAH-1, Ad-113 and Portland-1.

Characterization of isolates by allozyme electrophoresis. Sonicates of trophozoites were analysed by allozyme electrophoresis on cellulose acetate ('Cellogel', Chemetron, Milan) as described previously 

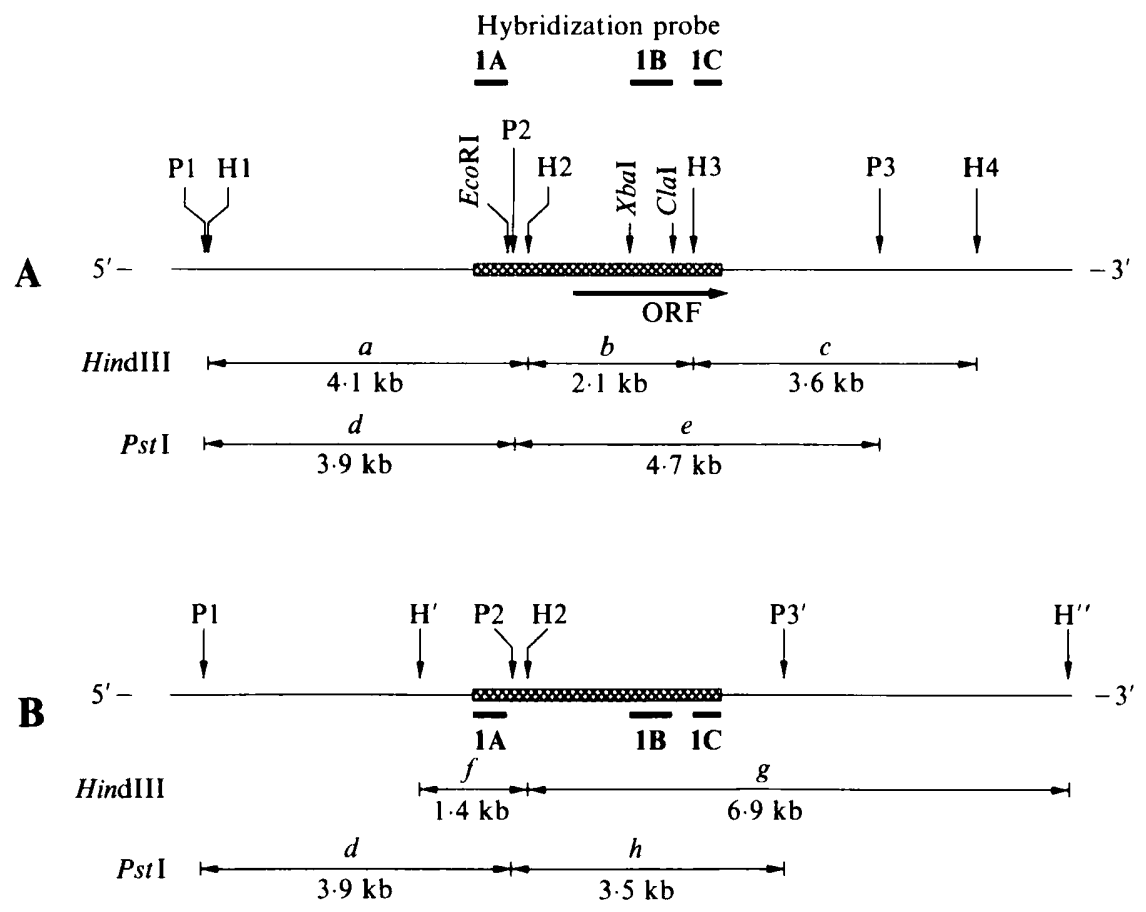

Fig. 1. Restriction map of Ad-1 chromosomal DNA (A) in the region of the $t s p 11$ gene cloned in pKK 11 , and predicted map of group II G. intestinalis DNA (B) over the corresponding chromosomal region. The genomic fragment (hatched box) of Ad-1 DNA cloned in plasmid pKK11, the location of the restriction fragments used to prepare hybridization probes $1 \mathrm{~A}, 1 \mathrm{~B}$ and $1 \mathrm{C}$, and the open reading frame (ORF, thick arrow) corresponding to $t s p I l$, are indicated. The single EcoRI, Pst $\left(\mathrm{P}_{2}\right), X b a \mathrm{I}$ and ClaI sites, and the two HindIII sites $\left(\mathrm{H}_{2}, \mathrm{H}_{3}\right)$, located within the pKK11 insert are shown (vertical arrows) in (A). The positions of two additional HindIII sites, one $\left(\mathrm{H}_{1}\right)$ upstream and the other $\left(\mathrm{H}_{4}\right)$ downstream of the cloned segment, as well as the two adjacent $P$ st $I$ sites $\left(\mathrm{P}_{1}, \mathrm{P}_{3}\right)$, are also shown in $(\mathrm{A})$. The predicted locations of the three HindIII sites $\left(\mathbf{H}^{\prime}, \mathbf{H}_{2}, \mathbf{H}^{\prime \prime}\right)$ and the three PstI sites $\left(\mathbf{P}_{1}, \mathbf{P}_{2}, \mathbf{P}_{3}{ }^{\prime}\right)$ detected in group II isolates are depicted in (B). The sizes of the predominant HindIII and PstI fragments detected in group I isolates $(a, b, c ; d, e)$ and in group II isolates $(f, g ; d, h)$ are shown.

(Andrews et al., 1989). Two clones derived from the Ad-1 and Ad-2 isolates were used as representatives of genetic groups I and II respectively (Andrews et al., 1989). BAH-12 (group III) and BRIS/87/ HEPU/694 (group IV) were also used as type standards.

Genomic DNA isolation. Chromosomal DNA was isolated from trophozoites by digestion at $37^{\circ} \mathrm{C}$ for $2 \mathrm{~h}$ with proteinase $\mathrm{K}$ $\left(0.2 \mathrm{mg} \mathrm{m}^{-1}\right)$ in $0.1 \mathrm{M}$-Tris/ $\mathrm{HCl}, 0.2 \mathrm{M}-\mathrm{NaCl}, 0.1 \mathrm{~m}-\mathrm{EDTA}, 1 \%(\mathrm{w} / \mathrm{v})$ SDS, pH 8.0. The digests were extracted twice with phenol/chloroform/isopentanol $(50: 48: 2$, by vol.), once with chloroform and then treated with boiled RNAase A $\left(50 \mu \mathrm{g} \mathrm{ml}^{-1} ; 3 \mathrm{~h}, 37^{\circ} \mathrm{C}\right)$. The DNA was precipitated in $70 \%(\mathrm{v} / \mathrm{v})$ ethanol, washed, and redissolved in $10 \mathrm{mM}-$ Tris/HCl, 1 mM-EDTA, pH 8.0 (TE).

Electrophoresis and hybridizations. Samples of DNA were incubated at $37^{\circ} \mathrm{C}$ with HindIII or PstI and the reactions monitored to ensure complete digestion. Samples containing $5 \mu \mathrm{g}$ of digested plasmid DNA or between 5 and $15 \mu \mathrm{g}$ of digested Giardia DNA were subjected to electrophoresis in $0.8 \%$ agarose gels in Tris/borate/EDTA (TBE). Gels were stained briefly with ethidium bromide, photographed, then immersed in $0.25 \mathrm{M}-\mathrm{HCl}(10 \mathrm{~min})$ and $0.5 \mathrm{M}-\mathrm{NaOH}, 1.5 \mathrm{M}-\mathrm{NaCl}$ $(25 \mathrm{~min}$ ) before being blotted onto positively charged nylon membranes by transfer in $0.4 \mathrm{M}-\mathrm{NaOH}$ for $6-12 \mathrm{~h}$. Each membrane was subsequently washed twice with $150 \mathrm{ml}$ aliquots of $2 \times \mathrm{PE}(1 \times \mathrm{PE}$ is $0 \cdot 133$ M-sodium phosphate, pH 6.9, plus 1 mM-EDTA), $0.1 \%$ SDS (10 min each) and then with $100 \mathrm{ml}$ of $5 \times \mathrm{PE}, 1 \% \operatorname{SDS}\left(3 \mathrm{~h}, 65^{\circ} \mathrm{C}\right)$. Prehybridization was carried out for $6-12 \mathrm{~h}$ at $42{ }^{\circ} \mathrm{C}$ in $20 \mathrm{ml}$ of $50 \%$ $(\mathrm{v} / \mathrm{v})$ formamide, $5 \times \mathrm{SSC}(1 \times \mathrm{SSC}$ is $0.15 \mathrm{M}-\mathrm{NaCl}$ plus $0.015 \mathrm{M}-$ sodium citrate), $5 \times$ Denhardt's solution, $50 \mathrm{~mm}$-sodium phosphate, pH 6.4, and $0.1 \mathrm{mg}$ herring sperm DNA $\mathrm{ml}^{-1}$. Digoxigenin-labelled probe $\left(0 \cdot 1-0.5 \mu \mathrm{g}\right.$ in $25 \mu \mathrm{l}$ of TE) was denatured at $95^{\circ} \mathrm{C}$ for $5 \mathrm{~min}$ and mixed immediately with $20 \mathrm{ml}$ of fresh hybridization solution, in which the filter was incubated for a further $12-18 \mathrm{~h}$ at $42^{\circ} \mathrm{C}$. Blots were washed at moderate stringency (twice at $25^{\circ} \mathrm{C}$ with $2 \times \mathrm{SSC}+0.1 \%$ SDS, then twice with $0.2 \times$ SSC $+0.1 \%$ SDS) and incubated with alkaline-phosphatase-conjugated anti-digoxigenin antibodies before staining with 5-bromo-4-chloro-3-indolyl phosphate (Boehringer Mannheim manual). For re-use, blots were destained in dimethylformamide, stripped of probe in $100 \mathrm{ml} 0.1 \% \mathrm{SDS}+0 \cdot 2 \mathrm{M}-\mathrm{NaOH}$ $\left(37^{\circ} \mathrm{C}, 30-60 \mathrm{~min}\right)$, rinsed in $2 \times \mathrm{SSC}$ and finally in water.

\section{DNA probes.}

Four probes were used. These were prepared from two genomic DNA fragments (from the Ad-1 $G$. intestinalis isolate) that had been cloned by ligation into the BamHI cloning site of plasmid pUC8. Probes 1A, 1B and $1 \mathrm{C}$ were derived from the recombinant plasmid $\mathrm{pKK} 11$, which contains a gene, $t s p 11$, that encodes a predicted $M_{\mathrm{r}} 69000$ cysteine-rich trophozoite surface protein, TSP11 (Ey et al., 1992), related to the TSA417 antigen described by Gillin et al. (1990). Probe 2 was prepared from an unrelated genomic fragment isolated from plasmid pKK $40(\mathrm{~K}$. Khanna, P. Ey \& G. Mayrhofer, unpublished results).

Probe 1A. EcoRI fragment of $\mathrm{pKK} 11$. This $0.43 \mathrm{~kb}$ fragment constitutes the $5^{\prime}$ non-coding end of the pKK 11 insert, commencing from the EcoRI site within the polylinker (see Fig. 1A). It lies upstream from HindIII site $\mathrm{H}_{2}$ (located $0.691 \mathrm{~kb}$ from the $5^{\prime}$ cloning site) and the 


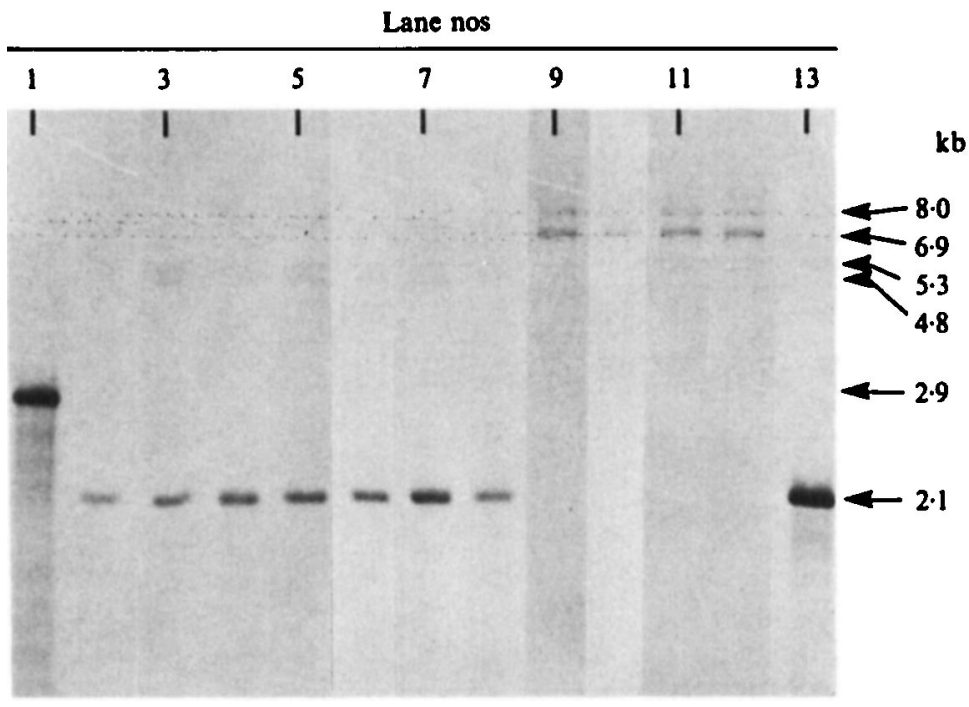

Fig. 2. Analysis of HindIII-digested genomic DNA from different $G$. intestinalis isolates by hybridization with probe $1 \mathrm{~B}$, specific for part of the $t$ sp 11 gene. The loading order was: Ad-1, Ad-3, Ad-6, Ad-10, BAH-1, Bris-768 and Portland-1 (lanes 2-8, allozyme group I); Ad-2, Ad-113, Bris-99 and Bris-136 (lanes 9-12, allozyme group II). Fragments produced by digestion of the plasmid pKK11 with SmaI or HindIII are evident in lane $1(2.9 \mathrm{~kb})$ and lane $13(2.1 \mathrm{~kb})$ respectively. Washing was done at moderate stringency. single open reading frame of $t s p l l$, which starts at $1.26 \mathrm{~kb}$ (Fig. 1A). The fragment was purified from an EcoRI digest of pKK 11 by electrophoresis in TBE on a $6 \%(\mathrm{w} / \mathrm{v})$ polyacrylamide gel. Probe $1 \mathrm{~A}$ was prepared by random hexamer priming (Feinberg \& Vogelstein, 1984) using the purified fragment as a template for labelling with digoxigenin-labelled dUTP (Boehringer Mannheim manual).

Probe 1 B. XbaI-ClaI fragment of pKK 11 . This $0.56 \mathrm{~kb}$ fragment lies within the $t s p / l$ gene (Fig. $1 \mathrm{~A}$ ). pKK 11 was digested with $\mathrm{XbaI}$ and $\mathrm{ClaI}$, the fragment was purified (see probe $1 \mathrm{~A}$ above) and a digoxigenin-labelled probe was prepared by random priming.

Probe 1C. HindIII fragment of $\mathrm{pKK} 11$. A digoxigenin-labelled probe was similarly prepared from the $0.38 \mathrm{~kb}$ HindIII fragment of pKK 11 . This fragment lies immediately downstream from $\mathrm{HindIII}$ site $\mathrm{H}_{3}$ (Fig. 1A) and extends to the HindIII site located within the polylinker at the 3 end of the pKK 11 insert. It comprises the promoter-distal portion of the $t s p 11$ gene.

Probe 2. EcoRI-HindIII fragment of pKK 40 . This $0.83 \mathrm{~kb}$ fragment has been fully sequenced (K. Khanna, P. Ey, \& G. Mayrhofer, unpublished results). It shows no homology with the pKK 11 insert and is devoid of potential reading frames. The insert was purified electrophoretically from an EcoRI-HindIII digest of pKK40 and used to prepare a digoxigenin-labelled probe by random priming.

\section{Results}

Detection of restriction fragments hybridizing with probes IA-C.

Probe $1 \mathrm{~B}$ is derived from a highly conserved region within $t s p 11$, a gene that encodes a $M_{\mathrm{r}} 69000$ cysteinerich trophozoite surface protein (Fig. 1A). The $3.186 \mathrm{~kb}$ fragment containing $t s p 11$ was cloned in pKK 11 from a genomic library of Ad-1 DNA and it has been sequenced completely (Ey et al., 1992; GenBank accession no. M95814). The promoter distal part of tspll exhibits substantial sequence homology, both at the nucleotide and amino acid level, with the $t s a 417$ gene (Gillin et al., 1990) that encodes a $M_{\mathrm{r}} 72500$ surface antigen on trophozoites of $G$. intestinalis isolate WB.

We have constructed a detailed restriction map of the regions flanking the pKK11 fragment in the Ad-1 genome and determined by high stringency blotting that there is only one copy of tsp 11. The locations of the chromosomal HindIII and PstI sites are depicted in Fig. 1A. Digestion of the pKK 11 insert with HindIII yields a $2.124 \mathrm{~kb}$ fragment (by cleavage at sites $\mathrm{H}_{2}$ and $\mathrm{H}_{3}$ ) that contains the entire $X b a \mathrm{I}-\mathrm{ClaI}$ segment corresponding to probe $1 \mathrm{~B}$ (cf. Fig. 2, lane 13). This probe hybridized with an equivalent $2 \cdot 1 \mathrm{~kb}$ fragment in HindIII digests of genomic DNA from Ad-1 (Fig. 2, lane 2) and six other $G$. intestinalis isolates (Ad-3, Ad-6, Ad-10, BAH-1, Bris-768, Portland-1; Fig. 2). The $2 \cdot 1 \mathrm{~kb}$ fragment hybridized strongly in each of these seven isolates. Three additional fragments of approximately $4.8,5.3$ and $7.2 \mathrm{~kb}$ hybridized only weakly. Because the washings were done at high stringency, it is likely that these faint bands represent either residual incompletely digested fragments or independent sequences with significant homology. The remaining four isolates (Ad-2, Ad-113, Bris-99, Bris-136) showed no evidence of a $2 \cdot 1 \mathrm{~kb}$ band, but instead a less intense $6.9 \mathrm{~kb}$ fragment was detected, with fainter bands of approximately $8 \mathrm{~kb}$ and $9 \mathrm{~kb}$. The eleven isolates could therefore be categorized into two groups, one (seven isolates) possessing the $2 \cdot 1 \mathrm{~kb}$ fragment and the other (four isolates) possessing a predominant, but less pronounced, $6.9 \mathrm{~kb}$ fragment. Allozyme analyses on replicates of the samples used for the Southern hybridization confirmed that all of the isolates of the former group also belonged to genetic group I whereas Ad-2, Ad-113, Bris-99 and Bris-136 
Table 1. Allozyme data on group I and group II isolates used in this study

The loci shown (see Andrews et al., 1989) are diagnostic for groups I and II (Gpt, Np1, Np2); groups I/II versus III/IV (Got, Gpt, $\mathrm{Mdh}, \mathrm{Me}, \mathrm{Npl}$ ); and groups III versus IV (Got, Npl). Allozymes are designated alphabetically in order of increasing electrophoretic mobility.

\begin{tabular}{lcccccc}
\hline \hline & \multicolumn{5}{c}{ Enzyme locus } \\
\cline { 2 - 7 } Isolate & Got & Gpt & Mdh & Me & Npl & Np2 \\
\hline Ad-1/C1 & a & b & a & c & a & a \\
Ad-3/C2 & a & b & a & c & a & a \\
Ad-6/C1 & a & b & a & c & a & a \\
Ad-10/Cl & a & b & a & c & a & a \\
BAH-1 & a & b & a & c & a & a \\
Bris-768 & a & b & a & c & a & a \\
Portland-1 & a & b & a & c & a & a \\
Ad-2/C2 & a & c & a & c & b & b \\
Ad-113 & a & c & a & c & b & b \\
Bris-99/C2 & a & c & a & c & b & b \\
Bris-136/C1 & a & c & a & c & b & b \\
Group III* & c & a & b & ab & d & b \\
Group IV* & bd & a & b & b & c & b \\
\hline \hline
\end{tabular}

- Reference standards (Andrews et al., 1989) were isolates BAH-12 (group III) and BRIS/87/HEPU/694 (group IV).

(which possessed the $6.9 \mathrm{~kb}$ fragment) belonged to group II. The data on six enzyme loci (diagnostic for groups IIV) are presented in Table 1.

To investigate further the differences between group I and group II isolates in this genomic region, separate blots (not shown) containing DNA cleaved with HindIII or PstI were hybridized with probe 1 A (representing the 5 ' non-coding end of the pKK 11 insert, between HindIII sites $\mathrm{H}_{1}$ and $\mathrm{H}_{2}$ of Ad-1 DNA) and subsequently with probe $1 \mathrm{C}$ (representing the $3^{\prime}$ coding end, between sites $\mathrm{H}_{3}$ and $\mathrm{H}_{4}$ ). The results, like those of Fig. 2, revealed two distinct groups. Using probe $1 \mathrm{~A}$, a single $3.9 \mathrm{~kb}$ Pst $\mathrm{I}$ fragment was identified in all eleven isolates, confirming that the same chromosomal region was being analysed in cells from both genetic groups (Fig. 1, fragment $d$ ). However, whereas all of the group I isolates yielded a single $4 \cdot 1 \mathrm{~kb}$ HindIII fragment (Fig. $1 \mathrm{~A}$; fragment $a$ ) that hybridized to the probe, the only band detected in HindIII-restricted DNA from the group II isolates corresponded to a $1.4 \mathrm{~kb}$ fragment (Fig. 1B, fragment $f$ ). The group II isolates therefore possess a unique HindIII site located only slightly upstream from the segment corresponding to probe $1 \mathrm{~A}$.

Hybridization with probe $1 \mathrm{C}$, comprising the conserved promoter-distal portion of the tsp 1.1 gene, was more complex. Two fragments, one hybridizing approximately twice as strongly as the other, were identified in both HindIII- and PstI-digested DNA from all group I isolates (data not shown). The HindIII fragments were
$3.6 \mathrm{~kb}$ (major band) and $4.8 \mathrm{~kb}$ (minor band), whilst the PstI fragments were $4.7 \mathrm{~kb}$ (major) and $3.5 \mathrm{~kb}$ (minor). Probe $1 \mathrm{C}$ also hybridized (but only weakly) to a single $H$ ind III and PstI fragment (6.9 kb and $3.5 \mathrm{~kb}$, respectively) from the group II isolates. The detection by probe $1 \mathrm{C}$ of two prominent restriction fragments in both HindIIIand PstI-digested DNA from group I isolates can be explained if these isolates possess the tsp 11 gene (or its equivalent) and also a second, related gene whose homology with tspll is higher in the region represented by probe $1 \mathrm{C}$ than in the other (upstream) regions detected with probes $1 \mathrm{~A}$ and $1 \mathrm{~B}$. The more readily detected bands would thus represent the tsp 11 gene, the $3.6 \mathrm{~kb}$ HindIII fragment resulting from cleavage at sites $\mathrm{H}_{3}$ and $\mathrm{H}_{4}$ (fragment $c$ ) and the $4.7 \mathrm{~kb}$ Pst I fragment from cleavage at sites $\mathrm{P}_{2}$ and $\mathrm{P}_{3}$ (fragment $e$ ) as depicted in Fig. 1A. If the fainter $4.8 \mathrm{~kb}$ HindIII fragment of group I isolates does represent an homologous second gene, it is unlikely to be a coincidence that the combined size of this fragment and the $2 \cdot 1 \mathrm{~kb}$ fragment $b$ of $t s p 11$ (Fig. 1A) is $6.9 \mathrm{~kb}$, equivalent to the major HindIII fragment detected in group II isolates with probe 1B (Fig. 1, fragment $g$ ). Indeed, the data are wholly consistent with the presence in group I isolates of two related genes, one of which has restriction characteristics similar (but not identical) to the homologous gene detected in group II isolates. The latter gene and its homologue in group II isolates appears to lack HindIII site $\mathrm{H}_{4}$ and has a new PstI site $\left(\mathrm{P}_{3}{ }^{\prime}\right.$, Fig. 1). The gene in group II isolates also lacks the $\mathrm{HindIII}$ site $\mathrm{H}_{3}$ and has an additional HindIII site $\mathrm{H}^{\prime}$ (Fig. 1B). The detection of the $6.9 \mathrm{~kb}$ HindIII fragment $g$ (Fig. 1B) in group II isolates and the $4.8 \mathrm{~kb}$ HindIII fragment (not shown in Fig. 1) as a minor band in group I isolates suggests that the tsp11like gene detected in group II organisms contains HindIII site $\mathrm{H}_{2}$. The $1.4 \mathrm{~kb}$ HindIII fragment detected in group II isolates with probe $1 \mathrm{~A}$ would therefore be formed by cleavage at sites $\mathrm{H}^{\prime}$ and $\mathrm{H}_{2}$ as depicted in Fig. $1 \mathrm{~B}$ (fragment $f$ ). Accordingly, it appears that HindIII site $\mathrm{H}_{2}$ and the two upstream PstI sites $\mathrm{P}_{1}$ and $\mathrm{P}_{2}$ are common to isolates from both genetic groups; two HindIII sites $\left(\mathrm{H}_{3}\right.$ and $\left.\mathrm{H}_{4}\right)$ and one downstream PstI site $\left(\mathrm{P}_{3}\right)$ are unique to group I organisms; and HindIII site $\mathrm{H}^{\prime}$ (Fig. 1B) is unique to group II organisms. Sites $\mathrm{H}_{3}$ and $\mathrm{H}^{\prime}$ therefore represent fixed genetic differences that appear to define these groups.

\section{Detection of restriction fragments hybridizing with} probe 2.

Probe 2 is unrelated to probes $1 \mathrm{~A}-\mathrm{C}$ and it hybridizes with many fragments in digests with various restriction enzymes of Ad-1 DNA (K. Khanna, P. Ey \& G. Mayrhofer, unpublished results). It appears, therefore, to 


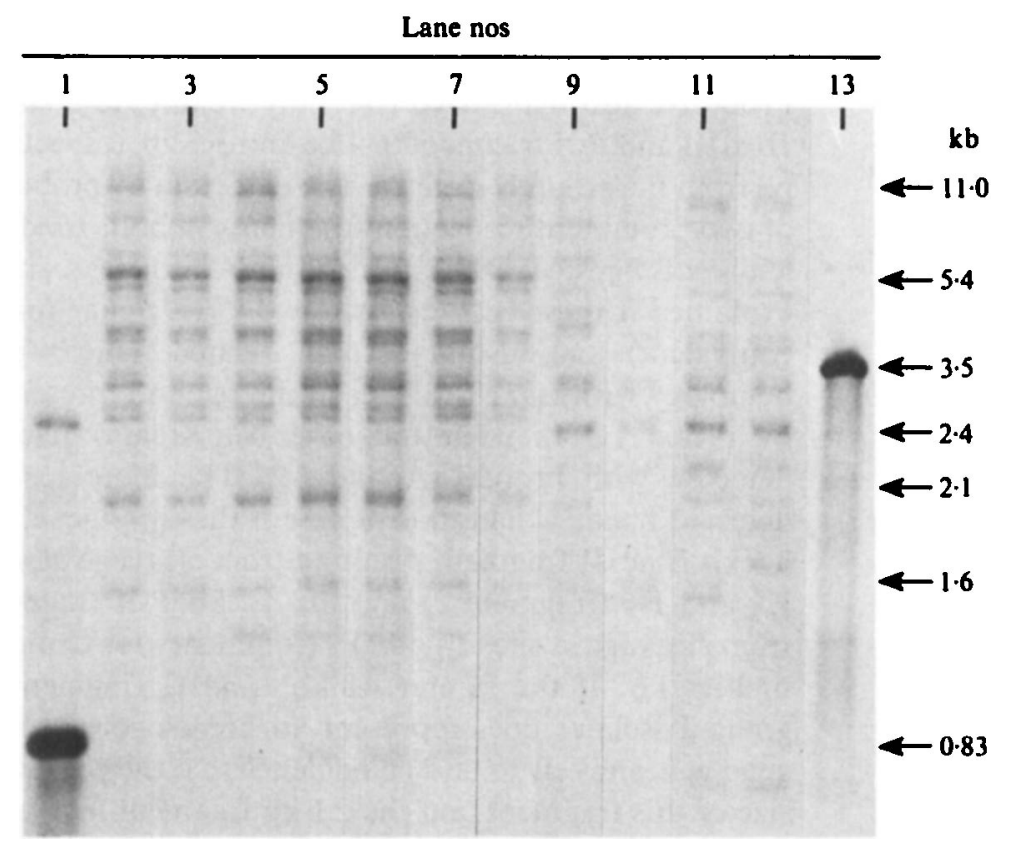

Fig. 3. Analysis of PstI-digested genomic DNA from different $G$. intestinalis isolates using probe 2 . The $0.83 \mathrm{~kb}$ insert of $\mathrm{pKK} 40$ (released by digestion with $E c o \mathrm{RI}+$ HindIII), is evident in lane $\mathrm{I}$ and the entire $3.5 \mathrm{~kb}$ plasmid (linearized with $E c o \mathrm{RI}$ ) is stained in lane 13. The Giardia DNA samples were: Ad-1, Ad-3, Ad-6, Ad-10, BAH-1, Bris-768 and Portland-1 (lanes 2-8); Ad-2, Ad-113, Bris-99, Bris-136 (lanes 9-12). Washing was done at moderate stringency. represent a sequence that exists in multiple copies within the genome and this contrasts with the unique or low copy gene detected with probes $1 \mathrm{~A}-\mathrm{C}$. Probe 2 identified numerous fragments in PstI digests of all the isolates tested (Fig. 3). Two banding patterns were evident, corresponding to the allozyme-defined groups I and II. The first pattern (group I; lanes 2-8) was invariant, both in the sizes $(0.8 \mathrm{~kb}$ to $\approx 12 \mathrm{~kb})$ and relative strength of hybridization of the fragments. At least 17 common bands were identified in every sample, with several very faint additional bands also evident. The most prominent bands corresponded to fragments of approximately $1.2 \mathrm{~kb}, 1.7 \mathrm{~kb}, 2.1 \mathrm{~kb}$ (strongly stained), 2.7 and $2.8 \mathrm{~kb}$ (doublet), 3.1 and $3.3 \mathrm{~kb}$ (doublet), 3.7 and $3.9 \mathrm{~kb}$ (doublet), $4.9 \mathrm{~kb}, 5.4 \mathrm{~kb}$ (the major band), $6.2 \mathrm{~kb}, 8.4 \mathrm{~kb}$ and $10.8 \mathrm{~kb}$.

The second pattern (group II; lanes 9-12) comprised fragments ranging in size from $0.7 \mathrm{~kb}$ to $10.4 \mathrm{~kb}$ and it was quite distinct from the group I pattern. Only two fragments (the 3.1 and $3.3 \mathrm{~kb}$ doublet band) could be considered common to all isolates from both groups (I and II). Four additional fragments (approximately $0.8 \mathrm{~kb}, 2.0 \mathrm{~kb}, 2.4 \mathrm{~kb}$ and $5.1 \mathrm{~kb}$ respectively) appear to be common to the four group II isolates and therefore specific for this group. However, these isolates were distinguished from each other by the presence (or absence) of a small number of additional bands, i.e. each isolate possessed a unique 'fingerprint'. The common $2.4 \mathrm{~kb}$ fragment hybridized most strongly to probe 2 , but overall the fragments from the group II isolates hybridized less well than did those of the group I isolates.

\section{Discussion}

This study describes the occurrence of restriction fragment length polymorphisms (RFLP) in isolates of $G$. intestinalis, detected by two DNA probes cloned from the genomic DNA of the Ad-1 isolate. In itself, this is not a novel finding because RFLPs have been described in $G$. intestinalis previously, using different DNA probes (Nash et al., 1985; de Jonckheere et al., 1989; Meloni et al., 1989). However, while of use in identifying similarities or differences between isolates, these studies have been of limited taxonomic value because only a few genetic characters (i.e. restriction sites) were examined in each isolate and the sequences detected by hybridization were otherwise uncharacterized. The unique value of the present study is that firstly, it has utilized a conserved gene whose sequence is known (Ey et al., 1992) and secondly, it was done concurrently with an electrophoretic analysis of 26 enzyme loci in the same strains, a technique which has been shown (Andrews et al., 1989) to distinguish genetic groups within $G$. intestinalis that exhibit fixed allelic differences at between $23 \%$ and $77 \%$ of the loci examined. In an earlier study, Meloni et al. (1989) also compared RFLP patterns (obtained with a different DNA probe) with electrophoretic analysis of allozymes in 47 axenic isolates of $G$. duodenalis. However, they presented their electrophoretic data as zymodemes, while we have used an allozymic interpretation and have quantified genetic relationships between isolates in terms of fixed allelic differences. We have therefore been able to relate RFLP patterns to 
Table 2. Grouping of G. intestinalis isolates according to restriction fragment length polymorphisms and allozyme patterns

\begin{tabular}{|c|c|c|c|c|c|}
\hline \multirow[b]{2}{*}{$\begin{array}{l}\text { Isolate } \\
\text { code }\end{array}$} & \multicolumn{3}{|c|}{$\begin{array}{c}\text { tsp11 gene } \\
\text { HindIII fragments }(\mathrm{kb})^{*}\end{array}$} & \multirow{2}{*}{$\begin{array}{c}\text { Repetitive } \\
\text { DNA } \\
\text { pattern } \dagger \\
\text { (probe 2) }\end{array}$} & \multirow[b]{2}{*}{$\begin{array}{l}\text { Allozyme } \\
\text { groupingt }\end{array}$} \\
\hline & $\begin{array}{l}\text { Probe } \\
1 \mathrm{~A}\end{array}$ & $\begin{array}{l}\text { Probe } \\
\text { 1B }\end{array}$ & $\begin{array}{l}\text { Probe } \\
\quad 1 \mathrm{C}\end{array}$ & & \\
\hline $\mathrm{Ad}-\mathrm{I} / \mathrm{Cl}$ & $4 \cdot 1 \S$ & $2 \cdot 1 \S$ & $3.6 \S \|$ & A & I \\
\hline $\mathrm{Ad}-3 / \mathrm{C} 2$ & $4 \cdot 1$ & $2 \cdot 1$ & 3.6 & A & I \\
\hline $\mathrm{Ad}-6 / \mathrm{Cl}$ & $4 \cdot 1$ & $2 \cdot 1$ & $3 \cdot 6$ & A & I \\
\hline $\mathrm{Ad}-10 / \mathrm{Cl}$ & $4 \cdot 1$ & $2 \cdot 1$ & $3 \cdot 6$ & A & I \\
\hline BAH-1 & $4 \cdot 1$ & $2 \cdot 1$ & $3 \cdot 6$ & A & I \\
\hline Bris-768 & $4 \cdot 1$ & $2 \cdot 1$ & $3 \cdot 6$ & A & I \\
\hline Portland-1 & $4 \cdot 1$ & $2 \cdot 1$ & $3 \cdot 6$ & A & I \\
\hline $\mathrm{Ad}-2 / \mathrm{C} 2$ & $1.4 \S$ & $6.9 \S$ & $6.9 \S$ & B1 & IIa \\
\hline Ad-1139 & $1.4^{\circ}$ & $6.9^{\circ}$ & $6.9^{\circ}$ & B2 & IIb \\
\hline Bris- $99 / \mathrm{C} 2$ & $1 \cdot 4$ & 6.9 & 6.9 & B4 & II \\
\hline Bris-136/Cl & $1 \cdot 4$ & 6.9 & 6.9 & B3 & II \\
\hline
\end{tabular}

* Based on RFLPs identified in HindIII-digested DNA using the probes indicated (Fig. 2) and data from other blots.

† From PstI-digested DNA (Fig. 3).

$\ddagger$ From Table 1 .

$\S$ Derived by cleavage with HindIII at sites (See Fig. 1) $\mathrm{H}_{1} \rightarrow \mathrm{H}_{2}$ (4.1 kb); $\mathrm{H}_{2} \rightarrow \mathrm{H}_{3}(2.1 \mathrm{~kb}) ; \mathrm{H}_{3} \rightarrow \mathrm{H}_{4}(3.6 \mathrm{~kb}) ; \mathrm{H}^{\prime} \rightarrow \mathrm{H}_{2}(1.4 \mathrm{~kb}) ; \mathrm{H}_{2} \rightarrow \mathrm{H}^{\prime \prime}$ $(6.9 \mathrm{~kb})$.

\| A $4.8 \mathrm{~kb}$ fragment, less heavily stained than the $3.6 \mathrm{~kb}$ fragment, was also evident in all group I isolates.

II Uncloned isolates.

established genetic groups and thus define restriction fragments that are unambiguously diagnostic for those groups. Conversely, the correlation between RFLP data and electrophoretic data adds weight to the genetic groupings defined by the latter technique.

The grouping of the eleven isolates examined in the present study is summarized in Table 2 . It is clear that the major RFLPs defined by probes $1 \mathrm{~B}$ and $1 \mathrm{C}$ (identifying sequences within the $M_{\mathrm{r}} 69000$ surface antigen gene cloned in $\mathrm{pKK} 11$ ) and by probe $1 \mathrm{~A}$ (specific for a region approximately $0.8 \mathrm{~kb}$ upstream from the start of this gene) correlate with the electrophoretic groups I and II defined by Andrews et al. (1989). The distinction of these genetic groups by these probes is not surprising, since it appears to be based on the simple loss or gain of restriction sites. We have not yet identified the precise nature of these mutations.

The repetitive sequence detected with probe 2 represents a more complex situation, but this probe also revealed group-specific differences. Furthermore, the detection of repetitive sequences enables sampling of a much larger portion of the genome than is possible using probes specific for unique genes, and this should increase the probability of detecting genetic differences between closely related isolates. This certainly appears to be the case for the group II isolates. Although there seems to be a substantial commonality of banding patterns within this group (Fig. 3; Table 2), the detection of minor differences between each of four group II isolates (but not between seven group I isolates, despite these being derived from diverse geographical areas) may indicate that group II is less homogeneous than group I. The number of samples examined so far in each group is very small, however, and many more isolates need to be compared before a definitive conclusion can be reached on this point.

We showed previously that group I and II isolates have fixed allelic differences at $31 \%$ of the 26 enzyme loci examined electrophoretically (Andrews et al., 1989). This level of genetic dissimilarity is typical of species differences in genera of sexual vertebrates (Richardson et al., 1986) and invertebrates (Chilton et al., 1992), and between species of protozoa with clear differences in morphology and geographic distribution (Andrews $e$ t al., 1988). The mutations underlying the restriction site differences (detected by the diagnostic RFLPs) that distinguish group I from group II organisms must have occurred subsequent to the divergence of the groups from . their common ancestor. These mutations may be relatively ancient but analysis of further samples is necessary to show whether the RFLP differences that they cause are indeed group-specific, or whether there is evidence of intragroup heterogeneity.

Electrophoretic groups III and IV have fixed allelic differences from groups I and II at $65-77 \%$ of the 26 enzyme loci examined by Andrews et al. (1989). We have not yet assessed the suitability of the DNA probes described herein for the study of these more distantly related $G$. intestinalis isolates or for morphologicallydistant species such as $G$. muris. The relatively weak hybridization of the pKK11 probes with DNA from group II isolates (which are less distantly related to group I isolates than are isolates of groups III/IV) makes this prospect unlikely. Furthermore, studies in progress (using oligodeoxyribonucleotides complementary to highly conserved sequences within the tsp 11 gene as primers for PCR amplification) indicate that the genetic divergence between groups $\mathrm{I} / \mathrm{II}$ and groups III/IV is too great to allow probes based on this gene to hybridize at high stringency (P. Ey, unpublished results). DNA probes specific for highly conserved structural genes (e.g. tubulin or giardin; reviewed by Adam, 1991) or sequence analysis of these genes may be more suitable adjuncts to allozyme electrophoresis (upper range, 60-70\% fixed allelic differences $\approx 20$ million years; Richardson et al., 1986) for studying the phylogenetic relationships between these more distantly related organisms.

It is now important to test the diagnostic grouping by RFLP analysis on a wider range of $G$. intestinalis from 
genetic groups I and II and to extend the studies to examine isolates from genetic groups III and IV and also $G$. duodenalis from animal sources. Furthermore, it is also important to recognize that analysis by Southern hybridization has severe limitations when applied to organisms such as Giardia. As was pointed out by Nash $e t$ al. (1985), this technique requires large amounts of DNA, essentially making in vitro culture a requisite. Unfortunately, many Giardia isolates cannot be grown in vitro and are available in very limited quantities (Mayrhofer et al., 1992). Application of PCR methodology to Giardia should circumvent these technical problems, because the technique has been applied successfully to single cysts (Mahbubani et al., 1992). However, the apparent failure of the latter study to detect differences between different members of the $G$. duodenalis group using primers specific for the $\beta$-giardin gene indicates that the choice of the target sequence may be critical. We are encouraged by the results presented herein to believe that judicious selection of diagnostic sequences (such as those described in the present study) will lead eventually to a systematics for the genus Giardia based principally on genetic rather than on morphological and other phenotypic characters.

We thank Ann Hallett and Jocelyn Darby for technical assistance and Robert Davey, who cloned the Ad-2 isolate. This work was supported by grants from the National Health and Medical Research Council of Australia, the Australian Research Council and the Channel 7 Children's Research Foundation of South Australia.

\section{References}

Abaza, S. M., Sullivan, J. J. \& Visvesvara, G. S. (1991). Isoenzyme profiles of four strains of Giardia lamblia and their infectivity to jirds. American Journal of Tropical Medicine and Hygiene 44, 63-68.

ADAM, R. D. (1991). The biology of Giardia spp. Microbiological Reviews 55, 706-732.

Adam, R. D., Nash, T. E. \& Wellems, T. E. (1988). The Giardia lamblia trophozoite contains sets of closely related chromosomes. Nucleic Acids Research 16, 4555-4567.

Andrews, R. H., Handman, E., Adams, M., Baverstock, P. R. \& MiTCHELL, G. F. (1988). Genetic characterization of Leishmania isolates at 37 enzyme loci. International Journal for Parasitology 18, 445-452.

ANDrews, R. H., ADAMs, M., Boreham, P. F. L., MaYrhofer, G. \& MELONI, B. P. (1989). Giardia intestinalis: electrophoretic evidence for a species complex. International Journal for Parasitology 19, 183190.

ANDrews, R. H., Chilton, N. B. \& MAYrhofer, G. (1992). Selection of specific genotypes of Giardia intestinalis by growth in vitro and in vivo. Parasitology 105, (in the Press).

Archibald, S. C., Mitchell, R. W., UpCroft, J. A., Boreham, P. F. L. \& UPCROFT, P. (1991). Variation between human and animal isolates of Giardia as demonstrated by DNA fingerprinting. International Journal for Parasitology 21, 123-124.

Baveja, U. K., Jyoti, A. S., Kaur, M., Aggarwal, D. S., Anand, B. S. \& NANDA, R. (1986). Isoenzyme studies of Giardia lamblia isolated from symptomatic cases. Australian Journal of Experimental Biology and Medical Science 64, 119-126.
Bertram, M. A., Meyer, E. A., Lile, J. D., \& Morse, S. A. (1983). A comparison of isoenzymes of five axenic Giardia isolates. Journal of Parasitology 69, 793-801.

Boreham, P. F. L., Phillips, R. E. \& Shepherd, R. W. (1987). Heterogeneity in the responses of clones of Giardia intestinalis to antigiardial drugs. Transactions of the Royal Society of Tropical Medicine and Hygiene 81, 406-407.

Campbell, S. R., van Keulen, H., Erlandsen, S. L., Senturia, J. B., \& JARROLL, E. L. (1990). Giardia sp.: Comparison of electrophoretic karyotypes. Experimental Parasitology 71, 470-482.

Chilton, N. B., Beveridge, I. \& ANDREws, R. H. (1992). Detection by allozyme electrophoresis of cryptic species of Hypodontus macropi (Nematoda: Strongyloidea) from macropodial marsupials. International Journal for Parasitology 22, 271-280.

ERLANDSEN, S. L. \& BemRICK, W. J. (1987). SEM evidence for a new species, Giardia psittaci. Journal of Parasitology 73, 623-629.

Erlandsen, S. L., Bemrick, W. J., Wells, C. L., Feely, D. E., Knudson, L., Campeell, S. R., van Keulen, H. \& Jarroll, E. L. (1990). Axenic culture and characterization of Giardia ardeae from the great blue heron (Ardea herodias), Journal of Parasitology 76, 717724.

Ey, P. L., Khanna, K., Manning, P. A. \& Mayrhofer, G. (1992). A gene encoding a $M_{\mathrm{r}} 69000$ major surface protein of Giardia intestinalis trophozoites. Molecular and Biochemistry Parasitology (in the Press).

FeELY, D. E. (1988). Morphology of the cyst of Giardia microti by light and electron microscopy. Journal of Protozoology 35, 52-54.

Feinberg, A. P. \& Vogelstein, B. (1984). A technique for radiolabelling DNA restriction endonuclease fragments to high specific activity. Analytical Biochemistry 132, 6-13.

FILICE, F. P. (1952). Studies on the cytology and life history of Giardia from the laboratory rat. University of California Publications in Zoology 57, 53-146.

Gillin, F. D., Hagblom, P., Harwood, J., Aley, S. B., Reiner, D. S., MCCAFFERY, M., So, M. \& GuineY, D. G. (1990). Isolation and expression of the gene for a major surface protein of Giardia lamblia. Proceedings of the National Academy of Sciences of the United States of America 87, 4463-4467.

DE JoNCKhEERE, J. F., GoRdTS, B., KASPRzAK, W., MAJEWSKA, A. C. \& MiCHELS, P. A. M. (1989). Cloning of a $1.8 \mathrm{~kb}$ repeated sequence for the identification and comparison of Giardia intestinalis isolates. European Journal of Protistology 24, 162-167.

de Jonckheere, J. F., Majewska, A. C. \& Kasprzak, W. (1990). Giardia isolates for primates and rodents display the same molecular polymorphism as human isolates. Molecular and Biochemical Parasitology 39, 23-28.

Kabnick, K. S. \& Peattie, D. A. (1991). Giardia: a missing link between prokaryotes and eukaryotes. American Scientist 79, 34-43.

KeISTER, D. B. (1983). Axenic culture of Giardia lamblia in TYI-S33 medium supplemented with bile. Transactions of the Royal Society of Tropical Medicine and Hygiene 77, 487-488.

van Keulen, H., Campbell, S. R., Erlandsen, S. L. \& Jarroll, E. L. (1991). Cloning and restriction enzyme mapping of ribosomal DNA of Giardia duodenalis, Giardia ardeae and Giardia muris. Molecular and Biochemical Parasitology 46, 275-284.

Lanzendörfer, M., Palm, P., GrampP, B., Peattie, D. A. \& Zillig, W. (1992). Nucleotide sequence of the gene encoding the largest subunit of the DNA-dependent RNA polymerase III of Giardia lamblia. Nucleic Acids Research 20, 1145.

Mahbubani, M. H., Bej, A. K., Perlin, M. H., Schaefer, F. W., III, JAKUBOWSKI, W. \& ATLAS, R. M. (1992). Differentiation of Giardia duodenalis from other Giardia spp. by using polymerase chain reaction and gene probes. Journal of Clinical Microbiology 30, 74-78.

MAYrhofer, G., ANDrews, R. H., Ey, P. L., Albert, M. J., GRIMMOND, T. R. \& MERRY, D. J. (1992). The use of suckling mice to isolate and grow Giardia from mammalian faecal specimens for genetic analysis. Parasitology 105, (in the Press).

Meloni, B. P., Lymbery, A. J. \& Thompson, R. C. A. (1988). Isoenzyme electrophoresis of 30 isolates of Giardia from humans and felines. American Journal of Tropical Medicine and Hygiene 38, 65-73. 
Meloni, B. P., Lymbery, A. J. \& Thompson, R. C. A. (1989). Characterization of Giardia isolates using a non-radiolabeled DNA probe, and correlation with the results of isoenzyme analysis. American Journal of Tropical Medicine and Hygiene 40, 629-637.

MEYER, E. A. (1976). Giardia lamblia: isolation and axenic cultivation. Experimental Parasitology 39, 101-105.

NASH, T. E. \& KEISTER, D. B. (1985). Differences in excretory-secretory products and surface antigens among 19 isolates of Giardia. Journal of Infectious Diseases 152, 1166-1171.

NaSh, T. E., McCutchan, T., Keister, D., Dame, J. B., ConRad, J. D. \& GILLIN, F. D. (1985). Restriction-endonuclease analysis of DNA from 15 Giardia isolates obtained from humans and animals. Journal of Infectious Diseases 152, 64-73.

Richardson, B. J., BAVerstock, P. R. \& AdAms, M. (1986). Allozyme Electrophoresis: a Handbook for Animal Systematics and Population Studies. Sydney: Academic Press.

Smith, P. D., Gillin, F. D., Kaushal, N. A. \& Nash, T. E. (1982).
Antigenic analysis of Giardia lamblia from Afghanistan, Puerto Rico, Ecuador and Oregon. Infection and Immunity 36, 714-719.

Sogin, M. L., Gunderson, J. H., Elwood, H. J., Alonso, R. A. \& Peattie, D. A. (1989). Phylogenetic meaning of the Kingdom concept : an unusual ribosomal RNA from Giardia lamblia. Science 243, 75-77.

SoUTHERN, E. M. (1975). Detection of specific sequences among DNA fragments separated by gel electrophoresis. Journal of Molecular Biology 98, 503-517.

Thompson, R. C. A., Lymbery, A. J. \& Meloni, B. P. (1990). Genetic variation in Giardia Kunstler, 1882: taxonomic and epidemiological significance. Protozoological Abstracts 14, 1-28.

UPCROFT, J. A., BOREHAM, P. F. L. \& UPCROFT, P. (1989). Geographic variation in Giardia karyotypes. International Journal for Parasitology 19, 519-527.

UPCROFT, J. A., UPCROFT, P. \& Boreham, P. F. L. (1990). Drug resistance in Giardia intestinalis. International Journal for Parasitology 20, 489-496. 